\title{
Efficacy of the Influenza Vaccine in Patients with Malignant Lymphoma
}

Joseph J. Mazza, MD, MACP; Steven H. Yale, MD, FACP; Jodi R. Arrowood, RPh; Cory E. Reynolds, MS; Ingrid Glurich, PhD; Po-Huang Chyou, PhD; James G. Linneman, BA and Kurt D. Reed, MD

Background: The benefits and efficacy of the influenza vaccine have been controversial and have had mixed reviews in the recent literature. Immunosuppressed patients and those receiving chemotherapy are particularly at risk for infectious complications and are therefore given high priority to receiving prophylactic vaccines.

Method: We administered the influenza vaccine to 29 patients with malignant lymphoma who were receiving chemotherapy or had recently completed therapy during the flu season of 2003-2004. An aged-matched control group received the same vaccine during the same period. The ability of both groups to mount a protective titer of antibodies to the antigens in the vaccine was measured.

Results: Three of 29 patients (10\%) in the lymphoma group were able to mount a 4-fold titer to at least one of the influenza $A$ antigens. One patient developed a protective titer to both influenza $A$ and B antigens and 3 of 29 responded to the influenza B antigen. In the control group I 3 of 29 (45\%) responded to an influenza $A$ antigen and 14 of $29(48 \%)$ had a 4 -fold response to the B antigen. Seven of 29 controls (24\%) had a 4 -fold increase in their titers to both the A and B antigens.

Conclusions: This study confirmed the low incidence of response or efficacy to the influenza vaccine reported in previous studies. Only a small percentage (10\%) of immunosuppressed patients with malignant lymphoma responded with a 4-fold increase in their antibody titer to the major antigens of the 2003 influenza vaccine. Most interestingly, less than $50 \%$ of the aged-matched control population studied responded with a 4-fold increase in their antibody titer. Additional studies are needed to determine methods for improving the efficacy of the vaccine and the effectiveness of the influenza vaccination program in preventing influenza infections in the United States.

\section{Keywords: Antigens, Influenza, Lymphoma, Titer, Vaccine}

I nfluenza is an important cause of morbidity and mortality worldwide. The elderly and those with underlying medical illnesses appear to be particularly vulnerable populations for influenza infection. Vaccination for individuals who are at increased risk for influenza infection and influenza-associated pneumonia has been recommended by the Centers for Disease Control and Prevention. ${ }^{1}$ This would include the elderly, individuals who have chronic disease or a malignancy, and those who are currently receiving immunosuppressive medications (e.g., corticosteroids, chemotherapy).2,3
The efficacy of this immunization program is often difficult to quantify since most studies in the current literature use surrogate endpoints and the parameters used to determine the response to vaccines vary from study to study. Pre- and post-immunization serum antibody titers are commonly used to measure the immunological response, with a 4-fold increase in antibody titer accepted as being indicative of vaccine efficacy. However, given the list of recommended immunizations for adults, it is unlikely that titers to determine the efficacy of each vaccine are measured and recorded subsequent to administration. Nowhere is this issue more 
clouded and confusing than the annual emphasis and media attention placed on the need to immunize virtually everyone in the United States against influenza infection. Every year, millions of Americans are urged to receive the "flu vaccine" during the fall months of the year to provide them with protection from "the flu" or, more specifically, influenza virus infections. Yet little data exist to determine the effectiveness of this immunization.

There are few studies in the current literature that provide credible data on the incidence of influenza infection each year in the United States. The data that are available are often inaccurate and unreliable, mainly due to the loose definition and interpretation of an influenza infection. Infections are usually recorded under the rubric of "the flu" or "flu-like illness" without documentation of an influenza viral infection. Most large studies on this subject use a variety of nonspecific systemic and subjective symptoms, e.g., fever, general malaise, headache, musculoskeletal aches and pains and pneumonia (flu-like illness), that are interpreted as representing the flu or influenza infection. These symptoms are frequently experienced in association with a host of other viral infections. ${ }^{4-16}$ Few of these studies document actual influenza viral infection by using direct fluorescence antibody testing, polymerase chain reaction (PCR) analysis and cell culture techniques to isolate and identify the virus.

The issue of providing protection to immunocompromised individuals with vaccines further compounds the problem of vaccine efficacy and effectiveness. Numerous studies have shown the inability of the immunocompromised host and individuals with malignant diseases to mount an adequate immunologic response to a variety of vaccines. In particular, lymphoreticular malignancies are inherently immunosuppressive and the patient's immune system is often further compromised by advanced age and aggressive chemotherapy regimens. ${ }^{17-23}$

In this study we enrolled 29 patients with a diagnosis of malignant lymphoma (Hodgkin's disease and non-Hodgkin's lymphoma) who were being treated with standard chemotherapy regimens or who had completed their chemotherapy within 3 months prior to receiving the influenza vaccine. Influenza antibody titers to the three antigens that constitute the vaccine were measured in each subject prior to administration of the vaccine and at various intervals thereafter to determine efficacy. The results were compared to those for age and gender-matched controls.

\section{Materials and Methods}

Study design

Twenty-nine patients with a diagnosis of malignant lymphoma (27 non-Hodgkin's lymphoma and 2 Hodgkin's disease) and 29 age- and gender-matched controls were acquired from the Marshfield Clinic healthcare system in Wisconsin. Subjects were required to be at least 18 years of age and have a life expectancy of at least 6 months. Age range for the lymphoma group (cases) was 32-81 years of age (median age 62 years). Age range in the control group was 35-82 years of age (median age 61 years). Subjects were excluded from eligibility into the study if they had a history of the following: (1) known or suspected allergy to eggs or egg products, (2) received immunoglobulins within the previous 90 days prior to vaccination or would be receiving immunoglobulins during the 60 days post-vaccination, (3) had a bone marrow or solid organ transplant, (4) planning to receive another vaccine during the study period, (5) were receiving corticosteroids $(7.5 \mathrm{mg}$ of prednisone minimum dose or its equivalent), (6) had an acute febrile illness at the time of vaccination, (7) Guillain-Barré syndrome, (8) neutropenia as defined by a white blood cell count of $<1.0 \mathrm{x}$ $10^{9} / 1$ or lymphopenia defined as a lymphocyte count of $1.0 \mathrm{x}$ $10^{9} / 1$. Twenty-one of the lymphoma patients in the case group were in the process of receiving chemotherapy; 8 had completed their chemotherapy within 3 months of entrance into the study. A mean of 27 days occurred from the last chemotherapy cycle start date to the administration of the influenza vaccine. The majority of cases had an Eastern Cooperative Oncology Group (ECOG) performance status of 0-1 signifying their ability to carry out normal daily activities with minimal signs and symptoms related to their disease.

Titers to the 3 major antigens contained in the vaccine were measured prior to its administration and again at 4, 12 and 24 weeks subsequent to vaccination for all study participants (cases and controls). A trivalent purified antigen vaccine, FLUVIRIN (Chiron Corp., Liverpool, England), containing antigens of type A (New Caledonia/20/99 [H1N1] and Panama/2007/99 [H3N2]) and type B (HongKong/330/2001-like virus) influenza virus, was administered intramuscularly into the deltoid area of the upper arm using a 1 inch \#25 gauge disposable needle during the 2003 influenza season (October through December). Each $0.5 \mu \mathrm{l}$ of vaccine contained $15 \mu \mathrm{g}$ of each influenza A and B hemagglutinin. Antibody titers to each of the 3 antigens were measured pre- and post-administration of the vaccine by means of the hemagglutinin inhibition test.

\section{Collection of patient sera}

Approximately $10 \mathrm{ml}$ of blood was drawn from study participants. Each sample was refrigerated for 30 minutes and then centrifuged at $1800 \mathrm{x} g$ at $4^{\circ} \mathrm{C}$ for 15 minutes. Serum was collected from each tube, transferred into appropriately labeled $1.8 \mathrm{ml}$ Cryule vials (Wheaton, Millville, NJ) and stored at $-80^{\circ} \mathrm{C}$ until assayed.

\section{Influenza antigens and sera}

Antigens and control sera were provided by Dr. Henrietta Hall, Centers for Disease Control and Prevention (CDC). Two influenza A antigens (New Caledonia/20/99 [H1N1] and Panama/2007/99 [H3N2]) and two influenza B antigens (B/Brisbane/32/02 and $\mathrm{B} / \mathrm{Sichuan} / 379 / 99$ ) were used to determine patients' serum titers in a hemagglutination inhibition assay. Because antigen to the $\mathrm{B} / \mathrm{Hong}$ Kong/330/01-like virus hemagglutinin was not available 
through $\mathrm{CDC}$, antigens of two very closely related viruses (B/Brisbane/32/02 and B/Sichuan/379/99) were used instead. In addition, control sera specific for each of the respective antigens were used to validate the assay. The lyophilized influenza A and B antigens were reconstituted in sterile distilled water and subjected to a hemagglutination assay to determine the number of hemagglutinating units (HAU) present or the amount of virus needed to agglutinate an equal volume of a standardized red blood cell (RBC) suspension.

\section{Receptor-destroying enzyme treatment of sera}

Sera were treated with receptor-destroying enzyme (RDE; Sigma-Aldrich, St. Louis, MO) as described elsewhere. ${ }^{24}$ The lyophilized product was reconstituted with $5 \mathrm{ml}$ sterile distilled water, diluted with $100 \mathrm{ml}$ calcium saline $(\mathrm{pH} 7.2)$, aliquoted and stored at $-20^{\circ} \mathrm{C}$. RDE was combined with each sera sample in a $4: 1$ ratio $(0.4 \mathrm{ml}$ RDE: $0.1 \mathrm{ml}$ serum $)$ and incubated overnight at $37^{\circ} \mathrm{C}$. Following the overnight incubation, 5 volumes $(0.5 \mathrm{ml})$ of $1.5 \%$ sodium citrate were added to each sample and incubated for 30 minutes at $56^{\circ} \mathrm{C}$ to inactivate the remaining $\mathrm{RDE}$.

\section{Standardization of $R B C s$}

Five milliliters of chicken RBCs (Rockland Immunochemicals, Inc., Gilbertsville, PA) were centrifuged at $1200 \mathrm{rpm}$ for 10 minutes and the supernatant aspirated. The remaining RBCs were gently resuspended in $50 \mathrm{ml}$ phosphate buffered saline (PBS; pH 7.2) and centrifuged at 1200 rpm for 5 minutes. The supernatant was aspirated and the RBCs washed 2 additional times before being resuspended to a final volume of $20 \mathrm{ml}$ in a $50 \mathrm{ml}$ conical centrifuge tube. The concentration adjusted to reach a $5 \%$ suspension.

\section{Hemagglutination assay}

Each influenza antigen was serially 2-fold diluted in PBS $(\mathrm{pH} 7.2)$ across a $\mathrm{V}$-shaped well microtiter plate to yield a volume of $50 \mu \mathrm{l}$. PBS alone was added to several wells to use as an assay control. After adding standardized RBCs $(50 \mu \mathrm{l})$ to each well, the plate was agitated and incubated at room temperature for 30 minutes. Hemagglutination titers were read as the reciprocal dilution of virus in the last well with complete hemagglutination.

\section{Hemagglutination inhibition assay}

Sera samples from each of the collected timepoints were assayed for reactivity to both influenza A and B antigens using a previously described World Health Organization protocol. ${ }^{24}$ Briefly, RDE-treated sera were serially 2-fold diluted in PBS ( $\mathrm{pH} 7.2$ ) to reach a volume of $25 \mu \mathrm{l}$. An equal volume $(25 \mu \mathrm{l})$ of appropriately diluted antigen (as determined by the hemagglutination assay; standard final HAU for the hemagglutination inhibition assay is 4 HAU) was added to each well receiving test sera. Additionally, wells were reserved for RBC control as well as back-titration for assay validation. The plates were agitated and incubated at room temperature for 15 minutes before $50 \mu l$ of standardized RBCs were added to each well on the plate. The plate was agitated again to mix well and incubated at room temperature for 30 minutes. Hemagglutination inhibition titers were read as the reciprocal of the serum dilution necessary to remove agglutination-inhibiting antibodies.

\section{Statistical analysis}

Titers converted to logarithmic scale, geometric means and 95\% confidence intervals were used for comparisons between the cases and the controls. Data were recorded as geometric mean titers of antibodies, mean increase in antibody titer, protection rate and response rate to hemagglutinin proteins. Comparisons in mean titer levels were made between cases and controls, separately at baseline, 1, 3 and 6 months. The statistical p-value was derived based on a Wilcoxon signed rank test for paired data. All statistical tests were two-sided and a p-value of $<0.05$ was considered to be statistically significant. The effect of previous vaccination status on vaccine efficacy and effectiveness was compared to those vaccinated in the past 5 years. Vaccine effectiveness was descriptive since the incidence of actual influenza cases observed was small. A proportional comparison between cases and controls using McNemar's test was done to determine whether the status of the titer was associated with lack of protection (titer $\geq 40$ after vaccination, but with a pre-vaccination titer $<40$ ) as well as response rate (i.e., 4-fold increase in titer after vaccination).

\section{Results}

Three (10\%) of the 29 subjects in lymphoma group (cases) and $13(45 \%)$ in the control group had a mean increase in titers to one of the major antigens of influenza A (signed-rank test with a p-value of $<0.05$ ) at baseline and at 3 and 6 months for H3N2. Nine patients $(31 \%)$ in the case group and 14 $(48 \%)$ in the control group had a 4-fold increase in titer to one of the major antigens (Sichuan and Hong Kong) of influenza $\mathrm{B}$ (signed-rank test $\mathrm{p}<0.05$ at baseline) at 1 and 3 months. Six $(20 \%)$ of the controls responded to both influenza B antigens.

In the lymphoma group, those that developed an adequate antibody titer (4-fold increase) did so at 12 weeks with the exception of 1 patient who developed a 4-fold increase at 4 weeks, while those in the control group had a 4-fold increase in their titer at 4 weeks subsequent to the administration of the vaccine which persisted at the 12 week interval.

A statistically significant 4-fold rise in antibody titer was found between the two groups for H1N1 at baseline and at 1 and 3 months for H3N2 antigen. There was no statistically significant difference in 4-fold rise in the antibody titer to influenza B antigens between the two groups (table 1). None of the patients in the lymphoma group responded to both $\mathrm{A}$ and B antigens, while 7 (24\%) controls had a 4-fold titer to both $\mathrm{A}$ and $\mathrm{B}$ antigens contained in the vaccine.

There was no statistically significant difference in the frequency of previous influenza vaccines administered in the past 5 years between the two groups ( $72 \%$ cases vs. $48 \%$ 
Table 1. Antibody kinetics in patients with lymphoma and age- and gender-matched controls vaccinated against influenza in the epidemic season 2003-2004.

\begin{tabular}{|c|c|c|c|c|c|c|}
\hline Vaccination & GMT & p-value & Protection* & p-value & $\begin{array}{l}\text { 4-fold change/ } \\
\text { response }\end{array}$ & p-value \\
\hline \multicolumn{7}{|c|}{ A/New Caledonia/20/99 (H1N1) } \\
\hline $\begin{array}{l}\text { Pre- } \\
\text { Cases } \\
\text { Controls }\end{array}$ & $\begin{array}{c}106.58 \\
50.80\end{array}$ & 0.0001 & & & & \\
\hline $\begin{array}{l}1 \text { month post } \\
\text { Cases } \\
\text { Controls }\end{array}$ & $\begin{array}{c}101.60 \\
99.20\end{array}$ & .09803 & $\begin{array}{l}0 \% \\
7 \%\end{array}$ & NA & $\begin{array}{r}0 \% \\
24 \%\end{array}$ & NA \\
\hline $\begin{array}{l}3 \text { months pos } \\
\text { Cases } \\
\text { Controls }\end{array}$ & $\begin{array}{l}86.67 \\
72.71\end{array}$ & 0.4000 & $\begin{array}{c}4 \% \\
12 \%\end{array}$ & 0.3173 & $\begin{array}{c}8 \% \\
27 \%\end{array}$ & 0.0956 \\
\hline $\begin{array}{l}6 \text { months pos } \\
\text { Cases } \\
\text { Controls }\end{array}$ & $\begin{array}{l}67.27 \\
78.11\end{array}$ & 0.2380 & $\begin{array}{l}4 \% \\
8 \%\end{array}$ & 0.5637 & $\begin{array}{l}17 \% \\
21 \%\end{array}$ & 0.7389 \\
\hline \multicolumn{7}{|c|}{ A/Panama/2007/99 (H3N2) } \\
\hline $\begin{array}{l}\text { Pre- } \\
\text { Cases } \\
\text { Controls }\end{array}$ & $\begin{array}{c}69.31 \\
101.60\end{array}$ & 0.0082 & & & & \\
\hline $\begin{array}{l}1 \text { month post } \\
\text { Cases } \\
\text { Controls }\end{array}$ & $\begin{array}{c}99.20 \\
251.97\end{array}$ & 0.0003 & $\begin{array}{c}7 \% \\
14 \%\end{array}$ & 0.4142 & $\begin{array}{r}3 \% \\
38 \%\end{array}$ & 0.0016 \\
\hline $\begin{array}{l}3 \text { months pos } \\
\text { Cases } \\
\text { Controls }\end{array}$ & $\begin{array}{c}89.00 \\
198.40\end{array}$ & 0.0014 & $\begin{array}{c}8 \% \\
12 \%\end{array}$ & 0.6547 & $\begin{array}{c}0 \% \\
31 \%\end{array}$ & NA \\
\hline $\begin{array}{l}6 \text { months pos } \\
\text { Cases } \\
\text { Controls }\end{array}$ & $\begin{array}{c}58.23 \\
129.03 \\
\end{array}$ & 0.0242 & $\begin{array}{c}8 \% \\
13 \% \\
\end{array}$ & 0.6547 & $\begin{array}{c}8 \% \\
29 \%\end{array}$ & 0.0956 \\
\hline \multicolumn{7}{|c|}{ B/Brisbane/32/02 } \\
\hline $\begin{array}{l}\text { Pre- } \\
\text { Cases } \\
\text { Controls }\end{array}$ & $\begin{array}{l}246.02 \\
426.30\end{array}$ & 0.0002 & & & & \\
\hline $\begin{array}{l}1 \text { month post } \\
\text { Cases } \\
\text { Controls }\end{array}$ & $\begin{array}{l}320.00 \\
774.86\end{array}$ & $<0.0001$ & $\begin{array}{l}0 \% \\
0 \%\end{array}$ & NA & $\begin{array}{c}7 \% \\
17 \%\end{array}$ & 0.0833 \\
\hline $\begin{array}{l}3 \text { months pos } \\
\text { Cases } \\
\text { Controls }\end{array}$ & $\begin{array}{l}311.58 \\
554.50\end{array}$ & 0.0059 & $\begin{array}{l}0 \% \\
0 \%\end{array}$ & NA & $\begin{array}{l}15 \% \\
19 \%\end{array}$ & 0.7055 \\
\hline $\begin{array}{l}6 \text { months pos } \\
\text { Cases } \\
\text { Controls }\end{array}$ & $\begin{array}{l}359.19 \\
655.48\end{array}$ & 0.0671 & $\begin{array}{l}0 \% \\
0 \%\end{array}$ & NA & $\begin{array}{l}17 \% \\
17 \%\end{array}$ & 1.0000 \\
\hline \multicolumn{7}{|c|}{ B/Sichuan/379/99 } \\
\hline $\begin{array}{l}\text { Pre- } \\
\text { Cases } \\
\text { Controls }\end{array}$ & $\begin{array}{l}447.17 \\
141.98\end{array}$ & $<0.0001$ & & & & \\
\hline $\begin{array}{l}1 \text { month post } \\
\text { Cases } \\
\text { Controls }\end{array}$ & $\begin{array}{l}774.86 \\
208.12\end{array}$ & $<0.0001$ & $\begin{array}{l}0 \% \\
7 \%\end{array}$ & NA & $\begin{array}{l}14 \% \\
10 \%\end{array}$ & 0.7055 \\
\hline $\begin{array}{l}3 \text { months pos } \\
\text { Cases } \\
\text { Controls }\end{array}$ & $\begin{array}{l}429.05 \\
218.31\end{array}$ & 0.0177 & $\begin{array}{l}0 \% \\
4 \%\end{array}$ & NA & $\begin{array}{c}4 \% \\
23 \%\end{array}$ & 0.0588 \\
\hline $\begin{array}{l}6 \text { months pos } \\
\text { Cases } \\
\text { Controls }\end{array}$ & $\begin{array}{l}905.10 \\
251.97\end{array}$ & 0.0003 & $\begin{array}{l}0 \% \\
4 \%\end{array}$ & NA & $\begin{array}{l}25 \% \\
25 \%\end{array}$ & 1.0000 \\
\hline
\end{tabular}

*Titer $\geq 40$ after vaccination but with pre-vaccination titer $<40$.

GMT, geometric mean titer. NA, not applicable. 
controls, $\mathrm{p}=0.08)$. Of the 58 subjects enrolled in both groups, 11 reported adverse effects related to the vaccine. At the 6-month follow-up, 4 subjects reported with a respiratory or flu-like illness. A nasopharyngeal swab specimen was obtained and assayed for influenza A and B by PCR and for cell culture studies to detect influenza A and B at each patient's visit. None of the 4 subjects tested positive for influenza A or B by $\mathrm{PCR}$ reaction.

\section{Discussion}

Most immunocompetent persons develop an effective immune response to influenza A and B within 10 to 14 days after vaccination. ${ }^{25-27}$ However, the inability to mount an adequate or protective titer of antibodies to a variety of vaccines in large segments of the population is well documented and the efficacy of certain vaccines has been difficult to determine.

High-risk segments of the population are identified as individuals who suffer from chronic illnesses, are on corticosteroids or other immunosuppressive agents, have a diagnosis of a malignant disease, are receiving chemotherapy and the elderly population of our society at large. Ironically, these are the very same groups that have the lowest response to vaccines by virtue of a compromise in their immune status.

Patients with a diagnosis of cancer and who are actively undergoing treatment are particularly at risk for acute and chronic infections and are, therefore, given priority in most vaccination programs being advocated. The literature, however, suggests that many of these individuals will have an inadequate response or be unable to develop a protective antibody titer to a variety of vaccines being administered. ${ }^{28}$

Serologic conversion rates of $19 \%-93 \%$ have been reported in adults with various malignancies, but patients with Hodgkin's disease and non-Hodgkin's lymphoma have demonstrated poor responses to multi-antigen vaccines as well as single antigen vaccines, including influenza vaccines, as compared to patients with solid tumors or non-hematologic malignancies. ${ }^{29-33}$ Prior exposure to influenza virus and previous influenza vaccinations have also been shown to suppress the production of antibodies and therefore influence the response to new influenza vaccines. ${ }^{34}$ Additionally, it has been demonstrated that older age individuals tend to have a weaker immune response than younger individuals. ${ }^{35-37}$

This study selected a homogenous group of patients with a hematologic malignancy (lymphoma) and confirmed the low incidence of response or efficacy of the influenza vaccine administered during the fall of 2003 (October 1 through December 20). Our sample size of lymphoma patients is too small to comment on the degree of immunosuppression caused by the various chemotherapeutic regimens used to treat this group of patients, however, given the low percentage of response it would appear that the immunosuppression, as is determined by the antibody titers measured subsequent to the vaccination, was not related to a specific regimen or agent used in treatment.

It also demonstrated a surprisingly low response (41\%) of the age-matched control group who had no history of medical illness or medications that would render them immunocompromised during the study period. Thus, it appears that more effective vaccination programs may be needed to protect those individuals deemed at risk from contracting communicable infections. Multiple studies have shown that a second dose of influenza vaccine can enhance the antibody response in both children and adults receiving chemotherapy who mounted an inadequate immunologic response to the initial dose. ${ }^{38-41}$ Whether the administration of additional or "booster" doses, or increasing the concentration of the antigen contained within the vaccine ${ }^{42,43}$ will improve the effectiveness of the vaccine remains to be determined.

Our study, although small, raises two important questions: (1) how effective is the influenza vaccine in preventing an acute influenza viral infection in individuals at increased risk of infection, i.e., the immunocompromised host? And (2), how effective is the influenza vaccine in preventing influenza viral infection in the general population who receives the vaccine each year?

Given the nonspecific and surrogate endpoints used to acquire these data without clear documentation of an influenza infection in the currently available literature, the incidence of influenza infection may be significantly overestimated. To support this contention, a recent update study on influenza activity in the United States showed that of the 130,577 respiratory specimens for influenza viruses acquired from collaborating laboratories throughout the country from individuals with "flu-like illnesses," only 24,649 (18.9\%) were positive. ${ }^{14}$ Thus, the influenza vaccination program may be more effective in preventing infection than previously estimated in a recently published study assessing the effectiveness of the influenza vaccine among children and adults. ${ }^{44}$

The strengths of our study include: (1) all cases tested for response had lymphoma and were exposed in a recent timeframe to immunosuppressive therapy, and (2) patient population (cases) and age-matched controls were all vaccinated and subsequently evaluated at the same institution. However, our study is limited by the small number of patients enrolled from which conclusions could be drawn and by the assumption that a 4-fold rise in antibody titer subsequent to the vaccination is representative of a positive response or a protective titer.

Large multicenter studies will be necessary to obtain accurate data to answer these important questions. Only then will we be able to determine the cost-benefit of the current influenza vaccination program. 


\section{Acknowledgments}

We thank Marshfield Clinic Research Foundation for its support through the assistance of Linda Weis and Alice Stargardt in the preparation of this manuscript.

\section{References}

1. Prevention and control of influenza: recommendations of the Advisory Committee on Immunization Practices (ACIP). Centers for Disease Control and Prevention. MMWR Recomm Rep 1998;47(RR-6):1-26.

2. Recommendations of the Advisory Committee on Immunization Practices (ACIP): use of vaccines and immune globulins for persons with altered immunocompetence. MMWR Recomm Rep 1993;42(RR-4):1-18.

3. Update on adult immunization. Recommendations of the Immunization Practices Advisory Committee (ACIP). MMWR Recomm Rep 1991;40(RR-12):1-94.

4. Nichol KL, Baken L, Nelson A. Relation between influenza vaccination and outpatient visits, hospitalization, and mortality in elderly persons with chronic lung disease. Ann Intern Med 1999;130:397-403.

5. Potter J, Stott DJ, Roberts MA, Elder AG, O’Donnell B, Knight PV, Carman WF. Influenza vaccination of health care workers in long-term-care hospitals reduces the mortality of elderly patients. J Infect Dis 1997;175:1-6.

6. Cifu A, Levinson W. Influenza. JAMA 2000;284:2847-2849.

7. Fedson DS, Wajda A, Nicol JP, Hammond GW, Kaiser DL, Roos LL. Clinical effectiveness of influenza vaccination in Manitoba. JAMA 1993;270:1956-1961.

8. Foster DA, Talsma A, Furumoto-Dawson A, Ohmit SE, Margulies JR, Arden NH, Monto AS. Influenza vaccine effectiveness in preventing hospitalization for pneumonia in the elderly. Am J Epidemiol 1992;136:296-307.

9. Mullooly J, Bennett M, Hornbrook M, et al. Cost-effectiveness of influenza vaccination programs in an HMO: the experience of Kaiser Permanente, Northwest Region. In: Hannoun C, Kendal AP, Klenk HD, Ruben FL, eds. Options for the control of influenza II. Amsterdam: Excerpta Medica; 1993. 53-62.

10. Nichol KL, Margolis KL, Wuorenma J, Von Sternberg T. The efficacy and cost effectiveness of vaccination against influenza among elderly persons living in the community. $\mathrm{N}$ Engl J Med 1994;331:778-784.

11. Simonsen L, Clarke MJ, Williamson GD, Stroup DF, Arden $\mathrm{NH}$, Schonberger LB. The impact of influenza epidemics on mortality: introducing a severity index. Am J Public Health 1997;87:1944-1950.

12. Govaert TM, Thijs CT, Masurel N, Sprenger MJ, Dinant GJ, Knottnerus JA. The efficacy of influenza vaccination in elderly individuals. A randomized double-blind placebo-controlled trial. JAMA 1994;272:1661-1665.

13. Glezen WP. Serious morbidity and mortality associated with influenza epidemics. Epidemiol Rev 1982;4:25-44.

14. Centers for Disease Control and Prevention (CDC). Update: influenza activity - United States and worldwide, 2003-04 season, and composition of the 2004-05 influenza vaccine. MMWR Morb Mortal Wkly Rep 2004;53:547-552.

15. Bridges CB, Thompson WW, Meltzer MI, Reeve GR, Talamonti WJ, Cox NJ, Lilac HA, Hall H, Klimov A, Fukuda K. Effectiveness and cost-benefit of influenza vaccination of healthy working adults: A randomized controlled trial. JAMA 2000;284:1655-1663.

16. Edwards KM, Dupont WD, Westrich MK, Plummer WD Jr, Palmer PS, Wright PF. A randomized controlled trial of cold-adapted and inactivated vaccines for the prevention of influenza A disease. J Infect Dis 1994;169:68-76.
17. Feldman S, Webster RG, Sugg M. Influenza in children and young adults with cancer: 20 cases. Cancer 1977; 39:350-353.

18. Ortbals DW, Liebhaber H, Presant CA, Van Amburg AL 3rd, Lee JY. Influenza immunization of adult patients with malignant diseases. Ann Intern Med 1977;87:552-557.

19. Ganz PA, Shanley JD, Cherry JD. Responses of patients with neoplastic diseases to influenza virus vaccine. Cancer 1978;42:2244-2247.

20. Shildt RA, Luedke DW, Kasai G, El-Beheri S, Laham MN. Antibody response to influenza immunization in adult patients with malignant disease. Cancer 1979;44:1629-1635.

21. Schafer AI, Churchill WH, Ames P, Weinstein L. The influence of chemotherapy on response of patients with hematologic malignancies to influenza vaccine. Cancer 1979;43:25-30.

22. Anderson H, Petrie K, Berrisford C, Charlett A, Thatcher N, Zambon M. Seroconversion after influenza vaccination in patients with lung cancer. Br J Cancer 1999;80:219-220.

23. Gross PA, Gould AL, Brown AE. Effect of cancer chemotherapy on the immune response to influenza virus vaccine: review of published studies. Rev Infect Dis 1985;7:613-618.

24. World Health Organization (WHO). WHO Manual on Animal Influenza Diagnosis and Surveillance. Webster RG and Krauss S, eds. Global Influenza Programme, World Health Organization. 2002.

http://www.wpro.who.int/avian/docs/WHO Manual on animal influenza.pdf

25. Gross PA, Russo C, Dran S, Cataruozolo P, Munk G, Lancey SC. Time to earliest peak serum antibody response to influenza vaccine in the elderly. Clin Diagn Lab Immunol 1997;4:491-492.

26. Lambkin R, Oxford JS, Biao L, Al-Jabri A, Fleming D. Rapid antibody response to influenza in "at risk" groups. Vaccine 2000;18:2307-2311.

27. Robertson JD, Nagesh K, Jowitt SN, Dougal M, Anderson H, Mutton K, Zambon M, Scarffe JH. Immunogenicity of vaccination against influenza, Streptococcus pneumoniae and Haemophilus influenzae type B in patients with multiple myeloma. Br J Cancer 2000;82:1261-1265.

28. Brydak LB, Rokicka-Milewska R, Jackowska T, Rudnicka H, Regnery H, Cox N. Kinetics of humoral response in children with acute lymphoblastic leukemia immunized with influenza vaccine in 1993 in Poland. Leuk Lymphoma 1997;26:163-169.

29. Arrowood JR, Hayney MS. Immunization recommendations for adults with cancer. Ann Pharmacother 2002;36:1219-1229.

30. Steinherz PG, Brown AE, Gross PA, Braun D, Ghavimi F, Wollner N, Rosen G, Armstrong D, Miller DR. Influenza immunization of children with neoplastic diseases. Cancer 1980;45:750-756.

31. Borella L, Webster RG. The immunosuppressive effects of long-term combination chemotherapy in children with acute leukemia in remission. Cancer Res 1971;31:420-426.

32. Sybesma JP, Holtzer JD, Borst-Eilers E, Moes M, Zegers BJ. Antibody response in Hodgkin's disease and other lymphomas related to HL-A antigens, immunoglobulin levels and therapy. Vox Sang 1973;25:254-262.

33. Feery BJ, Sullivan JR, Hurley TH, Evered MG. Immunization with influenza vaccine in patients with haematological malignant disease. Med J Aust 1977;1:292-294.

34. Powers RD, Hayden FG, Samuelson J, Gwaltney JM Jr. Immune response of adults to sequential influenza vaccination. J Med Virol 1984;14:169-175.

35. Keren G, Segev S, Morag A, Zakay-Rones Z, Barzilai A, Rubinstein E. Failure of influenza vaccination in the aged. J Med Virol 1988;25:85-89.

36. Strassburg MA, Greenland S, Sorvillo FJ, Lieb LE, Habel LA. Influenza in the elderly: report of an outbreak and a review of vaccine effectiveness reports. Vaccine 1986;4:38-44. 
37. Allison JE, Glezen WP, Taber LH, Paredes A, Webster RG. Reactogenicity and immunogenicity of bivalent influenza A and monovalent influenza $B$ virus vaccines in high-risk children. J Infect Dis 1977;136(suppl):S672-S676.

38. Lange B, Shapiro SA, Waldman MT, Proctor E, Arbeter A. Antibody responses to influenza immunization of children with acute lymphoblastic leukemia. J Infect Dis 1979; 140:402-406.

39. Sumaya CV, Williams TE, Brunell PA. Bivalent influenza vaccine in children with cancer. J Infect Dis 1977;136(suppl):S656-S660.

40. Brydak LB, Calbecka M. Immunogenicity of influenza vaccine in patients with hemato-oncological disorders. Leuk Lymphoma 1999;32:369-374.

41. Lo W, Whimbey E, Elting L, Couch R, Cabanillas F, Bodey G. Antibody response to a two-dose influenza vaccine regimen in adult lymphoma patients on chemotherapy. Eur J Clin Microbiol Infect Dis 1993;12:778-782.

42. Siber GR, Gorham C, Martin P, Corkery JC, Schiffman G. Antibody response to pretreatment immunization and post-treatment boosting with bacterial polysaccharide vaccines in patients with Hodgkin's disease. Ann Intern Med 1986;104:467-475.

43. Nicholson KG, Baker DJ, Chakraverty P, Farquhar A, Hurd D, Kent J, Litton PA, Smith SH. Immunogenicity of inactivated influenza vaccine in residential homes for elderly people. Age Ageing 1992;21:182-188.

44. Centers for Disease Control and Prevention (CDC). Assessment of the effectiveness of the 2003-04 influenza vaccine among children and adults - Colorado, 2003. MMWR Morb Mortal Wkly Rep 2004;53:707-710.

\section{Author Affiliations}

Joseph J. Mazza, MD, Department of Hematology/Oncology, Marshfield Clinic, Marshfield, Wisconsin

Steven H. Yale, MD, FACP, Department of Internal Medicine, Marshfield Clinic, and Clinical Research Center, Marshfield Clinic Research Foundation, Marshfield, Wisconsin

Jodi R. Arrowood, RPh, Pharmacy, St. Joseph's Hospital, Marshfield, Wisconsin

Cory E. Reynolds, MS, Clinical Research Center, Marshfield Clinic Research Foundation, Marshfield, Wisconsin

Ingrid Glurich, PhD, Clinical Research Center, Marshfield Clinic Research Foundation, Marshfield, Wisconsin

Po-Huang Chyou, PhD, Biostatistics and Bioinformatics Core, Marshfield Clinic Research Foundation, Marshfield, Wisconsin

James G. Linneman, MS, Biostatistics and Bioinformatics Core, Marshfield Clinic Research Foundation, Marshfield, Wisconsin

Kurt D. Reed, MD, Department of Pathology, Marshfield Clinic and Clinical Research Center, Marshfield Clinic

Research Foundation, Marshfield, Wisconsin 